AESTHETIC DEMOCRACY 



\section{AESTHETIC DEMOCRACY}

Thomas Docherty

STANFORD UNIVERSITY PRESS

STANFORD, CALIFORNIA

2006 
Stanford University Press

Stanford, California

(C) 2006 by the Board of Trustees of the Leland Stanford Junior University.

All rights reserved.

No part of this book may be reproduced or transmitted in any form or by any means, electronic or mechanical, including photocopying and recording, or in any information storage or retrieval system without the prior written permission of Stanford University Press.

Library of Congress Cataloging-in-Publication Data

Docherty, Thomas.

Aesthetic democracy / Thomas Docherty.

p. $\mathrm{cm}$.

Includes bibliographical references and index.

ISBN 0-8047-5188-9 (cloth : alk. paper)

ISBN 0-8047-5189-7 (pbk. : alk. paper)

I. Democracy—Philosophy. 2. Critical theory. I. Title.

JC423.D667 2006

$32 \mathrm{I} .8-\mathrm{DC} 22$

2005025801

Original Printing 2006

Last figure below indicates year of this printing:

$\begin{array}{llllllllll}\text { I5 } & \text { I4 } & \text { I3 } & \text { I2 } & \text { II } & \text { IO } & 09 & 08 & 07 & 06\end{array}$ 
For Bridie May Sullivan and Hamish J. S. Docherty 
